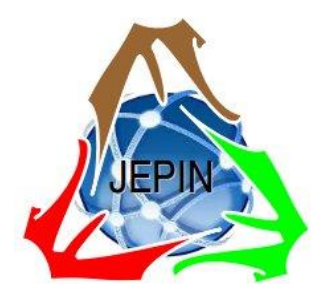

\title{
Exploitation with Reverse_tcp method on Android Device Using Metasploit
}

\author{
Rizky Dwiananda Lukita Putra $^{\# 1}$, Is Mardianto ${ }^{* 2}$ \\ Program Studi Teknik Informatika, Universitas Trisakti \\ ${ }^{1}$ rizky064014000060std.trisakti.ac.id \\ ${ }^{2}$ mardianto@trisakti.ac.id \\ Universitas Trisakti
}

Jl. Letjen S. Parman No. 1, RT.6/RW.16, Tomang, Grogol Petamburan, Kota Jakarta Barat, Daerah Khusus Ibukota Jakarta, 11440.

\begin{abstract}
Android is a popular operating system on smartphone which run on linux kernel. Android operating system allows developers to access and modify source code, but this advantage also increases the security issue. One of the various attack is exploit, that many attacker carry out this type of attack to get sensitive user information. In this research, exploit attacks are done used some tool such as metasploit framework and this experiment is done on android device which one be a target attack. The result obtained from this exploit attack in the form of an understanding of how to conduct exploit attack, analyze the interaction of attacker with victim, analyze the workings of exploit attack and how long will it take to set up a payload with bash script shell. All the details of the analyze will give us the conclusions and strategies to make the android operating system more secure.
\end{abstract}

Kata kunci - Exploit, Android Device, Metasploit, Kali linux, Bash script shell

\section{Pendahuluan}

Teknologi selalu berkembang dan mengalami kemajuan sangat pesat sesuai dengan perkembangan zaman dan perkembangan cara berfikir manusia itu sendiri, sebuah informasi yang serba digital membawa manusia ke dunia yang revolusioner karena dirasa mudah, murah dan praktis untuk berkomunikasi dan memperoleh informasi yang merupakan tujuan adanya perkembangan.

Perkembangan ini pula mempunyai dampak negative berupa pencurian data sensitif para pengguna perangkat android. Android adalah sistem operasi seluler berbasis kernel linux. Kernel linux menyediakan sifat multi-user dan control disrectionary access control (DAC) diatas semua layer android. Android menggunakan mekanisme sandboxing dan isolation tingkat kernel untuk memisahkan aplikasi dari satu sama lain, dan untuk mengontrol komunikasi antara aplikasi atau akses sumber daya. Ini berarti bahwa smartphone yang dipilih karena kemudahan dan kesederhanaan dalam mengakses aplikasi. Dengan adanya sebuah perangkat smartphone, pertukaran informasi dapat dikembangkan lebih pesat dibandingkan dengan teknologi sebelumnya dan alat ini memiliki beberapa fungsi lain yang dapat memberikan hiburan dan pengkasesan informasi melalui akses internet[16]. Oleh Karena itu android menjadi salah satu sistem operasi yang paling banyak digunakan, terdapat sejumlah besar aplikasi yang terinfeksi oleh malware seperti spyware,backdoords, Trojan hourse, dan lain-lain. Aplikasi backdoor memberikan penyerang ke berbagai izin dari perangkat yang terpasang[1]

Banyak cara seorang penyerang melakukan serangan backdoors dengan menyerang keamanan secara spesifik salah satunya exploit dengan bantuan tool metasploit yang merupakan software security yang sering digunakan untuk menguji ketahanan pada suatu sistem jenis serangan ini berjalan pada application layer [2]

Motivasi dari penelitian ini untuk mengetahui karakteristik exploit dengan menggunakan metode serangan reverse tcp pada perangkat berbasis Android, dan ingin mengetahui variabel waktu yang dibutuhkan payload untuk masuk kedalam sistem dari target yang diserang.

Permasalahan dalam menerapkan serangan exploit pada penelitian ini adalah menemukan kerentanan (vulnerability) dari bagian-bagian (bug) system Android. Hal ini bisa dilakukan dengan cara mengekspoitasi fungsi yang terdapat baik pada bagian servis/layanan system Android atau pada bagian fisik penyimpanannya.

Kontribusi yang akan dihasilkan dari penelitian ini berupa pemahaman bagaimana metode reverse tcp bekerja dalam serangan exploit sistem Android dan bagaimana cara menghindarinya.

\section{STUDI LITERATUR}

\section{A. Bash script shell}

Pada percobaan ini penulis menggunakan bantuan script bash shell bernama ezsploit untuk mengkonfigurasi payload[15], dan pada bash script shell ini juga penulis 
melakukan perhitungan lamanya waktu yang diperlukan untuk melakukan satu kali konfigurasi payload. Untuk dapat melakukan perhitungan waktu, penulis menambahkan beberapa fungsi date di bash script shell.

Serangan exploit ini berjalan pada sistem operasi kali linux dan dibagian ini penulis memperkenalkan dan menjelaskan istilah-istilah yang dipakai dalam percobaan exploit, sebagai berikut.

\section{B. Metasploit Framewok}

Metasploit framework adalah platform pengujian dan pengembangan penetrasi open source yang memberi akses ke kode exploit untuk berbagai aplikasi, sistem operasi dan platform. Ditulis dalam Bahasa scripting Ruby dengan sifat status Ruby sebagai Bahasa berorientasi objek. Selain itu, metasploit dianggap multi-platform berjalan pada sebagian besar variasi unix dan windows[3].

Metasploit framework menghasilkan cara kerja yang luar biasa, tetapi bagi pengguna baru terbilang sulit untuk digunakan karena metasploit di linux tidak menyediakan graphic user-interface(GUI). Oleh karena itu perlu mengetahui sintaks dan perintah untuk menggunakan metasploit secara efektif. Dalam metasploit, untuk sebagian besar serangan perlu mengikuti langkah-langkah dasar yang disebutkan dibawah ini[4] :

- Memilih dan mengkonfigurasi (kode yang memasuki sistem target dengan mengambil keuntungan dari salah satu bug tersebut)

- Memilih dan mengkonfigurasi payload (kode yang akan dieksekusi pada sistem target jika berhasil masuk)

- Memilih teknik pengkodean sehingga sistem intrusi pencegahan mengabaikan payload

\section{- $\quad$ Mengeksekusi exploit}

Untuk memilih exploit dan payload, beberapa informasi tentang sistem target diperlukan, seperti versi sistem operasi dan layanan jaringan terpasang.

\section{Payload}

Payload adalah kode yang kita inginkan agar sistem dieksekusi dan itu harus dipilih dan disampaikan oleh framework sebagai contoh, reverse shell adalah payload yang membuat koneksi dari mesin target kembali ke penyerang sebagai meterpreter console, sedangkan bind shell adalah payload yang mengikat meterpreter console untuk mendengarkan pada port mesin target dimana penyerang dapat terhubung. Payload juga menjadi sesuatu dari beberapa perintah yang akan dijalankan pada sistem operasi target [5]. Berikut tipe-tipe payload untuk android :

- Android/meterpreter/reverse_tcp.

- Android/meterpreter/reverse_http.

- Android/metepreter/reverse_https.

- Android/shell/reverse_tcp.

\section{Meterpreter}

Meterpreter memberikan penyerang akses ke payload yang terpasang pada perangkat android target, dan penyerang kemudian dapat mengeksekusi perintah untuk membaca, memodifikasi, mengambil data atau informasi dari serangan exploit [6].

\section{ANDROID DRM SERVICE}

Platform android menyediakan DRM framework yang dapat diperluas yang memungkinkan aplikasi mengelola konten yang dilindungi hak sesuai dengan batasan lisensi yang terkait dengan konten. DRM framework android diimplementasikan dalam dua lapisan arsitektur [12]:

- DRM framework API aplikasi yang melewati $\mathrm{drm}$ framework dan berjalan melalui dalvik VM untuk aplikasi standar.

- DRM manager yang mengimplementasikan framework DRM dan memaparkan antarmuka untuk plug-in $D R M$ untuk menangani manajemen hak dan dekripsi berbagai skema $D R M$.

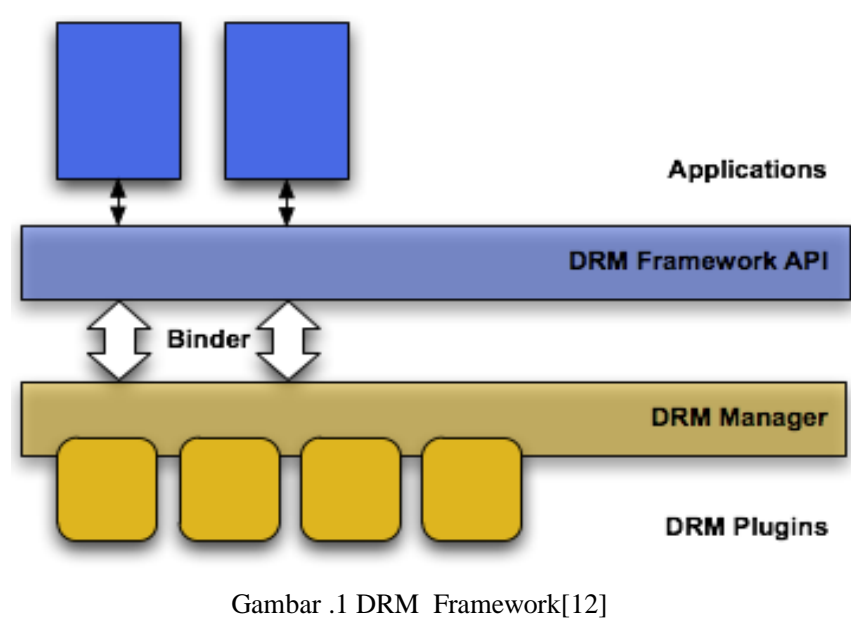

\section{ANDROID PLATFORM ARCHITECTURE}

Platform android dibuat oleh android Inc yang kemudian dibeli oleh google dan menyebutnya Android Open source Project. Platform android didasarkan pada kernel linux, yang dimodifikasi untuk memenuhi kebutuhan khusus manajemen daya yang lebih baik. Karena android dirancang untuk digunakan pada smartphone dan tablet, android memiliki banyak perubahan dan pembaruan pada kernel linux untuk mendukung perangkat yang berbeda. Penambahan termasuk subsistem untuk mengontrol memori dan prosesor, perpustakaan untuk mengelola sistem file yang dirancang untuk penyimpanan, manajemen proses dan manajemen perangkat. Kumpulan perangkat lunak android dapat dibagi menjadi lima lapisan : 
- Kernel linux dan perangkat tingkat yang lebih rendah

- System libraries

- Android runtime

- Application framework

- Application layer diatas semuanya

Setiap lapisan menyediakan layanan yang berbeda ke lapisan tepat di atasnya [7].

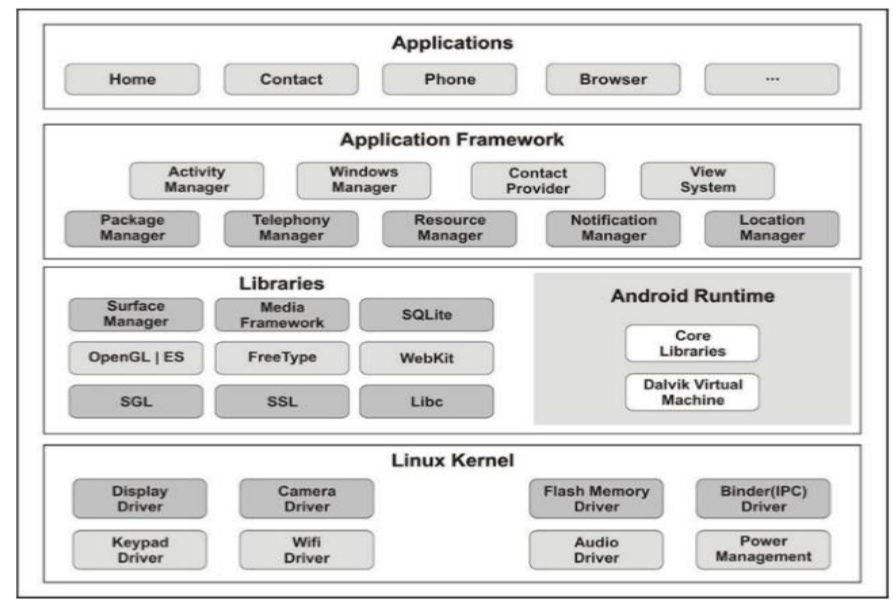

Gambar 2 . Arsitektur andaroid

\section{A. Linux Kernel}

Kernel linux adalah lapisan dasar yang setara dengan tingkat abstrak antara lapisan perangkat keras dan lapisan perangkat lunak lainya dalam sistem. Kernel berisi sejumlah besar driver perangkat yang membuat antarmuka ke perangkat keras sekelilingnya mudah dipahami [7].

\section{B. Libraries}

Di atas kernel linux ada seperangkat libraries C / C ++ asli android. Libraries khusus untuk perangkat keras tertentu. Sebagai contoh, media framework library memandu pemutaran dan perekaman berbagai gambar, video dan format audio. Beberapa libraries inti lainya termasuk surface manager, SQLite, Webkit, dan OpenGL.

\section{Android Runtime}

Android runtime termasuk set libraries java inti. Programmer aplikasi menggunakan Bahasa pemrograman java untuk mengembangkan aplikasi. Ini termasuk mesin virtual dalvik dan perpustakaan java core.

- Dalvik virtual machine : virtual machine berjalan seolah-olah itu adalah perangkat independen yang memiliki sistem operasinya sendiri. Ini memungkinkan banyak contoh mesin virtual untuk dijalankan secara bersamaan menyediakan isolasi, keamanan, manajemen memori. Setiap aplikasi berjalan sebagai prosesnya sendiri didalam mesin virtual sehingga tidak ada aplikasi lain yang bergantung padanya dan jika terjadi crash aplikasi, itu tidak akan mempengaruhi aplikasi lain yang berjalan pada perangkat. Fitur-fitur ini disebut sandbox [7].

- Core java libraries : sebagian besar fungsi yang didefinisikan dalam libraries java SE, termasuk tugastugas seperti penanganan string, jaringan dan manipulasi file disediakan oleh libraries ini.

D. Application Framework

Application framework mengelola fungsi smartphone seperti manajemen sumber daya, manajemen panggilan suara. Aplikasi dari lapisan atas berinteraksi dengan lapisan application framework. Beberapa blok penting dari application framework adalah aktivitas manajer, penyedia konten, manajer lokasi dan manajer sumber daya [7].

\section{E. Applications}

Application adalah lapisan paling atas dari arsitektur android. Pengguna rata-rata kebanyakan berinteraksi dengan lapisan ini untuk melakukan fungsi dasar seperti membuat panggilan telepon, mengakses browser. Exploit sebagai terjadi pada layer application yang memungkinkan penyerang untuk mengeksekusi kode ddan menyediakan akses yang tidak diauntetikasi ke beberapa sumber yang dilindungi.

\section{PROSES EXPLOIT}

Pada percobaan exploit penulis menggunakan perangkat android untuk dijadikan target percobaan dengan informasi sistem operasi android sebagai berikut :

- Android Versi 7.1.2 Nougat.

- Kernel versi 3.4.0

- Root status : no-root

Selain android yang dijadikan target, penulis juga menggunakan tool yang terpasang pada sistem operasi kali linux rolling versi 2018.2 yaitu Metasploit.

Langkah-langkah untuk melakukan percobaan exploit yaitu konfigurasi, konfigurasi listener dan menjalankan exploit.

\section{A. Konfigurasi Payload}

Ditahap konfigurasi payload, penulis menggunakan bash shell script bernama ezsploit yang dijadikan cara untuk membuat sebuah payload. berikut adalah representasi perintah yang ada pada tahap konfigurasi sebuah payload. perintah yang dituliskan pada terminal berupa shell script. Shell script menyederhanakan proses pembuatan payload ke file apk android [1]. Kode ini juga mendefinisikan tipe payload yang dimiliki oleh aplikasi backdoor. Penyerang dapat melakukan seranganya dengan membuat payload (.apk) mengetik alamat IP penyerang sebagai LHOST dan nomor port penyerang sebagai LPORT ke dalam perintah msfvenom $-p$ android/meterpreter/reverse_tcp $\quad$ LHOST=(alamat IP 
penyerang) LPORT=(nomor port penyerang) $R>$ /root/shell.APK [9]. Pada percobaan ini penulis menggunakan metode reverse_tcp dimana metode ini adalah jenis shell reverse meterpreter, reverse shell dapat melewati firewall, karena korban yang akan membuat sambungan kembali ke penyerang, sehingga pada metode listener pada mesin penyerang akan menuggu koneksi masuk, berikut skema perbedaan meotde reverse_tcp dengan bind_tcp :

Bind Shell TCP

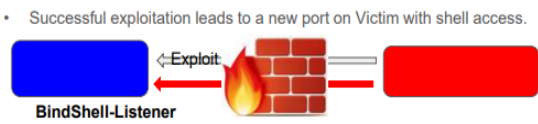

Reverse Shell TCP

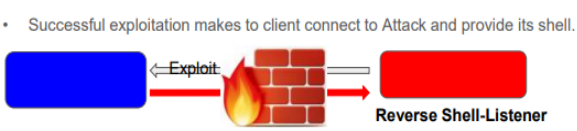

Gambar. 3 Skema reverse_TCP[13]

Berikut adalah gambar 4 shell.apk yang telah dibuat dengan mengeksekusi perintah pada gambar 3 dengan melalui proses yang terjadi dibelakang layar. Dimana file ini yang akan dikirim ke perangkat android target untuk dipasang.

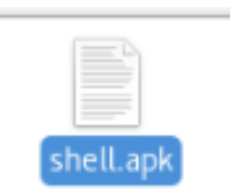

Gambar. 4 Payload bernama Shell.Apk

Setelah proses konfigurasi payload berhasil, selanjutnya adalah melakukan instalasi payload pada perangkat android yang dijadikan target, tahap ini penulis melakukan instalasi payload di android yang sebelumnya telah dijelaskan mengenai informasi android tersebut, setelah proses instalasi selesai tahap berikutnya adalah konfigurasi listener agar tercipta meterpreter sessions. Berikut langkah konfigurasi listener [8]:

- Buka Konsol metasploit dengan eksekusi perintah msfconsole.

- Setelah menu msfconsole terbuka, eksekusi perintah use multi/handler yang berfungsi penyerang dapat menentukan jenis payload dan mengatur LHOST serta LPORT untuk membuat listener.

- set payload android/meterpreter/reverse_tcp perintah ini berfungsi mengatur jenis payload.

- set LHOS <alamat IP penyerang> perintah ini berfungsi mengatur alamat IP yang akan digunakan sebagai host.
- set LPORT <nomor Port penyerang> perintah ini berfungsi mengatur nomor Port yang digunakan sebagai jalur masuk koneksi.

- exploit perintah ini memulai eksploitasi dengan membuat koneksi antara android target dan penyerang pada mesin listener.

Berikut adalah tampilan konfigurasi listener yang penulis telah lakukan dengan mengeksekusi setiap perintah sebelumnya.

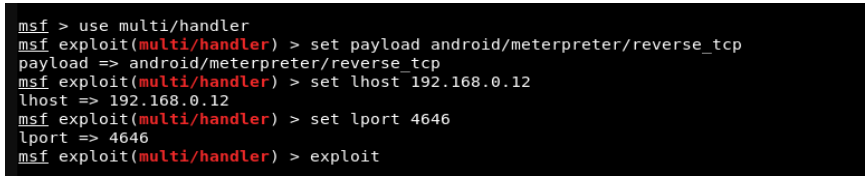

Gambar. 5 Konfigurasi listener

Pada Gambar 5 ditahap ini penyerang akan menunggu koneksi masuk ke listener, apabila payload yang telah terpasang pada android dibuka oleh korban itu menciptakan meterpreter sessions yang memungkinkan penyerang menjalankan kode eksploitasi. Dalam percobaannya untuk menguji apakah serangan exploit telah berhasil dan dapat berjalan, penulis mengeksekusi beberapa perintah untuk melakukan ujicoba keberhasilan serangan, berikut perintah yang penulis eksekusi pada saat meterpreter sessions tercipta :

- $\quad$ sysinfo perintah ini berfungsi untuk mengetahui informasi sistem android target. Hasilnya :

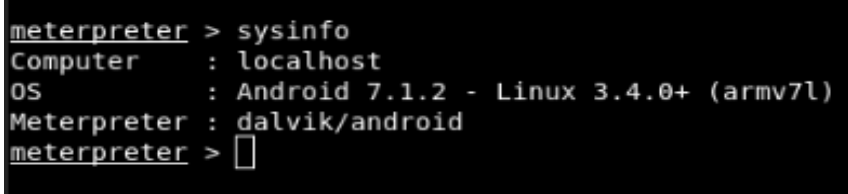

Gambar.6 Hasil eksekusi perintah sysinfo

Hasil dari perintah sysinfo adalah sebuah android dengan informasi versi OS Android 7.1.2 Linux 3.4.0 dimana diketahui informasi android yang dijadikan target mempunyai informasi sama, yang dapat dipastikan bahwa serangan exploit sudah berhasil dijalankan. Untuk mengetahui perintah-perintah yang ada pada metasploit kita dapat mengeksekusi perintah help di konsol meterpreter dengan begitu akan muncul kumpulan perintah yang mempunyai fungsi berbeda untuk melakukan eksploitasi lanjut ke perangkat android.

\section{PERHITUNGAN WAKTU}

Setelah penulis menambahkan fungsi pada bash script, penulis selanjutnya melakukan percobaan perhitungan waktu pada setiap ujicoba konfigurasi payload exploit disatu jaringan dan exploit dibeda jaringan, penulis juga akan menjelaskan bagaimana cara mendapatkan lamanya waktu yang dibutuhkan.

Setelah melakukan percobaan perhitungan waktu pada konfigurasi payload, dapat disimpulkan konfigurasi 
payload dengan menggunakan alamat IP lokal memerlukan waktu mulai hingga akhir rata-rata 27.29204 milliseconds dalam seratus kali percobaan perhitungan waktu lamanya sebuah payload selesai dikonfigurasi. Angkat tersebut didapatkan dari perhitungan rumus (\$\{akhir $\}$ - \$ mulai $\})$ dimana variable akhir adalah waktu dimana script ini selesai menjalankan setiap konfigurasi payload dalam satuan waktu milliseconds sedangkan variable mulai adalah waktu dimana script ini berjalan mengeksekusi baris pertama perintah pada script dalam satuan waktu milliseconds sehingga dari perhitungan ini diketahui hasil waktu lama konfigurasi payload.

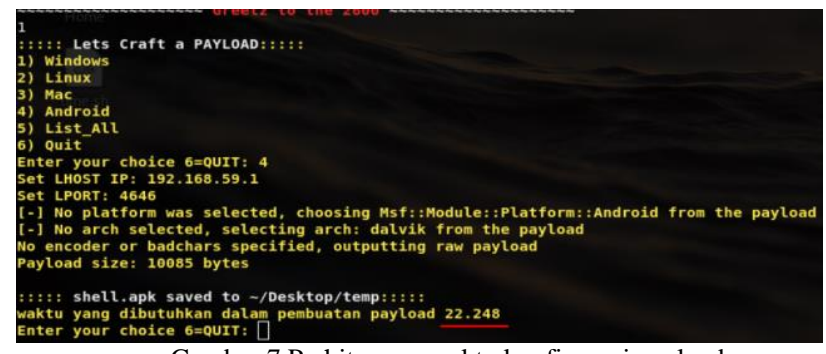

Gambar.7 Perhitungan waktu konfigurasi payload

\section{ANALISA}

Payload adalah sebuah muatan sederhana yang tersusun sepadat mungkin dan melakukan tugas menyediakan sarana untuk penyerang menggugah sesuatu yang lebih besar. Payload sering digunakan pada skenario eksploitasi karena serangan jenis exploit dapat menghasilkan ruang untuk shellcode dapat tersimpan.

Baris pertama perintah shellcode (sering disebut sebagai stage0) yang dapat membuat koneksi baru kembali ke mesin penyerang dan membaca sebuah payload yang lebih besar kedalam memori. Dalam istilah metasploit, payload ini disebut reverse_tcp dan tahap kedua (stage1) merupakan perintah shell standar seperti shell meterpreter.

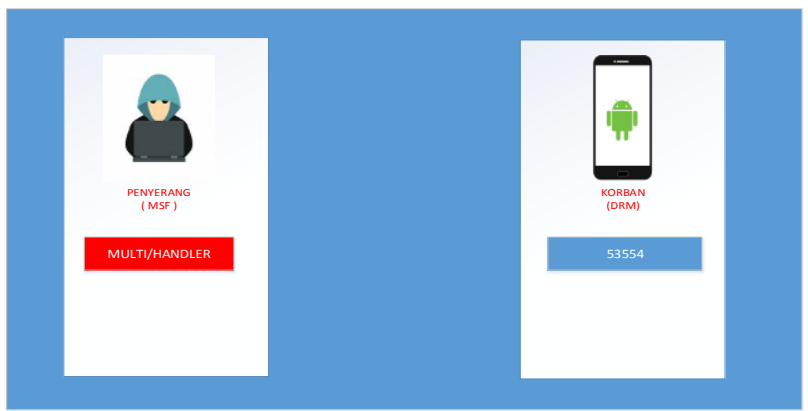

Gambar.8 Representasi mesin penyerang dan target

Saat kita menjalankan perintah set payload android/meterpreter/..... perintah ini berjalan dengan fungsi meminta metasploit untuk menyiapkan payload yang dipecah menjadi dua tahap, ditahap pertama memberi kita sebuah meterpreter sessions dan tahap kedua memberi kita alamat memori untuk mengeksekusi payload selanjutnya. Pada gambar 8 adalah sebuah representasi dari dua mesin, penyerang dan target. Pada mesin pertama berjalan sebuah metasploit dengan modul multi/handler yang telah dikonfigurasi oleh stage0 diatur menggunakan reverse_tcp dengan port 4646. Dan mesin kedua yaitu android menjalankan servis DRM (digital right management) pada port 53554

Ketika payload dieksekusi, metasploit membuat listener pada port yang ditentukan, kemudian membuat koneksi seperti ditunjukkan pada gambar 9 ke servis DRM (digital right management) android. Dibelakang layar ketika servis DRM (digital right management) target menerima sebuah koneksi, sebuah fungsi pada metasploit dipanggil, dimana fungsi tersebut berisikan stack buffer yang akan dikirim ke perangkat target.

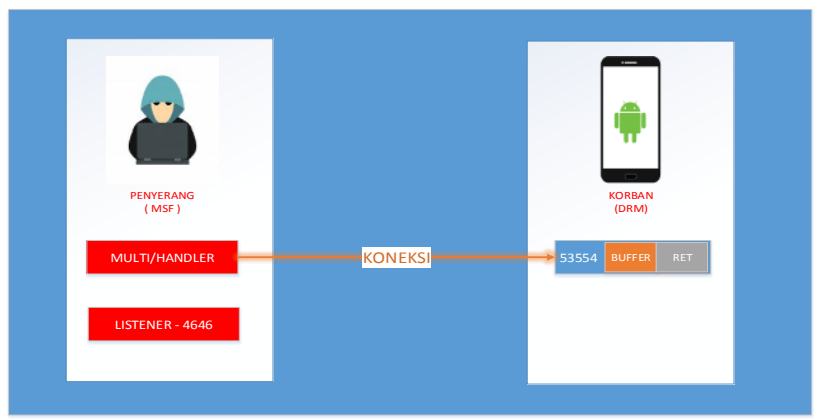

Gambar.9 Koneksi ke servis drm target

Mesin penyerang kemudian mengirim data seperti ditunjukkan pada gambar 10 yang lebih besar dari yang diperkirakan target. Data ini berisikan stage0 dan exploitspecific code, yang nantinya data ini akan membuat memori buffer target menjadi overflow. Fungsi dari exploit-specific code yang dikirim yaitu memungkinkan penyerang untuk mendapatkan kontrol atas binder[10]. Binder adalah mekanisme komunikasi antar proses ( IPC inter-proces communication) dimana pada IPC terdapat bug dalam validasi masukan IPC memungkinkan penyerang mengeksekusi kode dengan izin lebih tinggi dari aplikasi yang tidak berhak. Dan pada gambar 9 tahap ini sebuah exploit-specific code mengalihkan proses eksekusi ke shellcode (stage0).

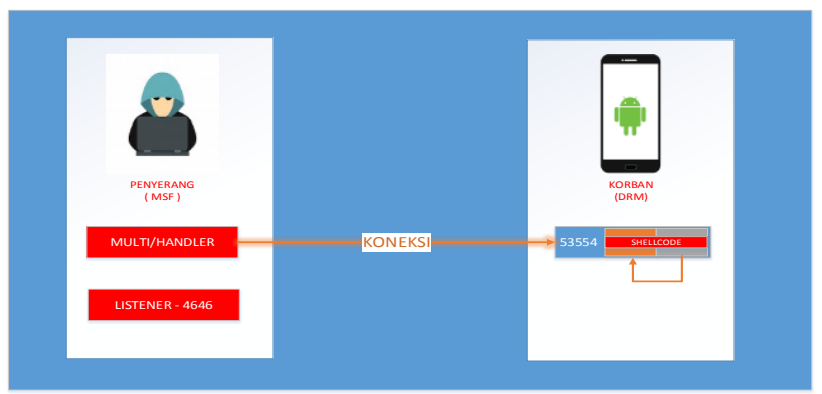

Gambar.10 Penyerang mengirim data ke mesin target 


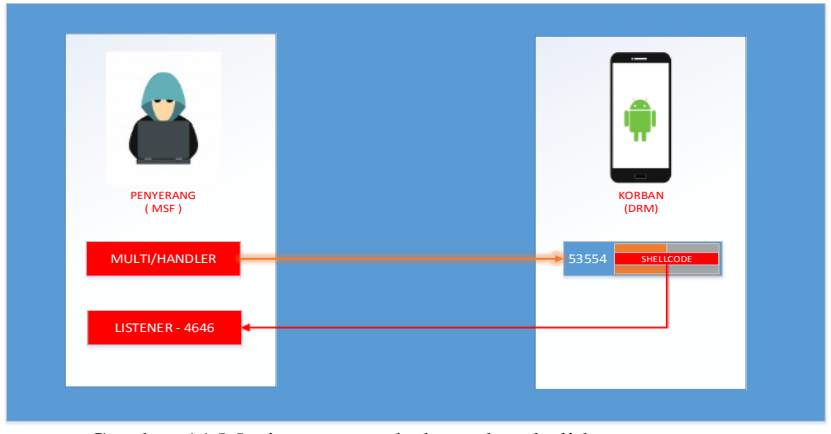

Gambar.11 Mesin target terhubung kembali ke penyerang

Pada gambar 11, ditahap ini penyerang memiliki kontrol eksekusi dalam layanan DRM, ketikan stageO (reverse_tcp) tereksekusi, stageO menghubungkan kembali ke mesin penyerang pada port yang ditentukan, yang siap menunggu stage1. Dalam kasus ini meterpreter stagel adalah sebuah file apk yang disebut shell. Merupakan data yang dikirim pada tahap gambar 11 .

Shell.apk kemudian dikirim ke mesin target melalui koneksi reverse (terbalik). Inilah yang terjadi ketika kita melihat pesan "sending stage (70031 bytes)" pada msfconsole.

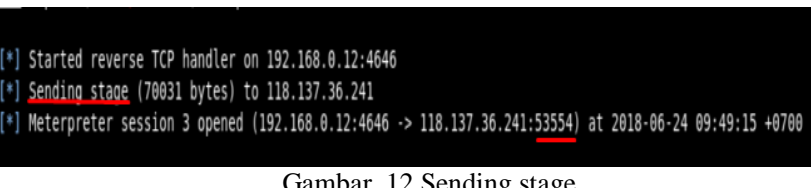

Angka 70031 bytes yang ditampilkan pada gambar. 12 mewakili seluruh shell.apk setelah data ini dikirim ke perangkat target, shellcode (stage0) menulis ke dalam memori.

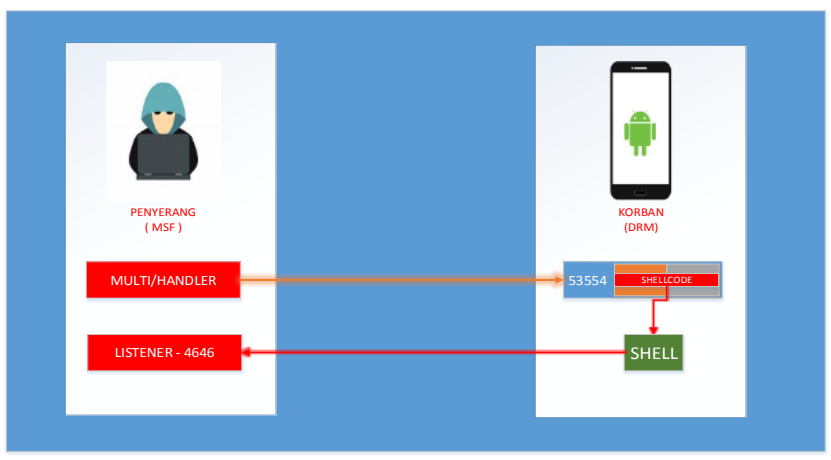

Gambar.13 Tampilan saat mesin target menjalankan shell.apk

Setelah stagel berada didalam memori, stage0 melewati kontrol dengan melompat ke lokasi dimana payload ditulis. Dalam kasus ini shell.apk mempunyai kumpulan shellcode yang terlihat mirip dengan header android yang valid, dimana shell.apk tidak akan terdeteksi sebagai apk yang mencurigakan oleh sistem android, ketikan dijalankan shell.apk dipetakan ulang dan memuat shell.apk ke dalam memori sedemikian rupa sehingga memungkinkanya berfungsi dengan benar sebagai sebuah file apk normal tanpa menuliskan ke disk atau mendaftarkan dengan proses host. Pada gambar 13 tahap ini sebuah meterprer siap menerima command shell pada konsol metepreter.

\section{KESIMPULAN}

Pada serangan exploit di android, terdapat kesimpulan yang bisa diambil setelah melakukan percobaan tersebut, bahwa karakteristik serangan exploit memanfaatkan dua bug yang terdapat pada sistem operasi android, yaitu pada penyimpanan memori fisik dan servis binder yang berjalan pada DRM (digital right management) memungkinkan aplikasi mengelola konten yang dilindungi hak sesuai dengan batasan lisensi yang terkait dengan konten.

Berikut ini temuan yang didapatkan dari teknik reverse tcp pada perangkat Android:

\section{A. Bug pada memori android}

Buffer overflow adalah bug dalam program yang dapat menyebabkan kerentanan keamanan. Buffer adalah bagian dari penyimpanan memori fisik yang sementara digunakan untuk menyimpan data. Buffer overflow terjadi ketika sebuah program atau proses mencoba untuk menulis atau membaca lebih banyak dari buffer yang dapat disimpan.

Dalam konteks keamanan, buffer overflow dapat memberikan akses penyerang ke berbagai bagian memori internal dan pada akhirnya mengontrol pelaksaan aplikasi [11]. Hubungan dalam percobaan ini saat mesin penyerang mengirim fungsi exploit-specific code ke stack buffer target, yang mempunyai ukuran lebih besar dari yang disediakan target, sehingga menyebabkan terjadi buffer overflow dan fungsi exploit-specific code mempunyai akses ke berbagai bagian memori internal dan akses mengontrol pelaksanaan program.

B. Bug Android Binder

Model keamanan yang sangat umum digunakan dalam banyak sistem operasi (termasuk android) berada dilingkup IPC (inter-proces communication). Bug pada validasi masukan IPC memungkinkan penyerang mengeksekusi kode dengan izin lebih tinggi dari aplikasi yang tidak berhak [10].

Dalam android, mekanisme IPC disebut binder. Binder memiliki banyak fitur yang memungkinkan proses untuk mentransfer objek yang kompleks antara satu sama lain. Dan bug pada binder ini yang dimanfaatkan oleh serangan exploit. Untuk mendapatkan izin akses setiap servis yang ada pada android untuk dijalankan.

\section{Reverse_tcp}

Serangan exploit pada percobaan ini menggunakan metode reverse_tcp yaitu metode penyerang memberikan perintah kepada korban, untuk melakukan koneksi masuk ke mesin listener penyerang.

\section{Port}

Penggunaan port pada serangan exploit berfungsi sebagai jalur komunikasi masuk dan keluar antara mesin 
penyerang dengan mesin korban saat terjadinya serangan exploit.

\section{E. Payload}

Ketika Payload yang terpasang dibuka oleh korban, payload malakukan koneksi pada mesin listener melalui port yang telah ditentukan.

D. Exploit Android

Serangan exploit masih dapat berjalan pada perangkat android 7.1.2 yaitu android Nougat.

Berikut adalah skema serangan exploit berdasarkan kesimpulan dari percobaan yang sudah dilakukan penulis :

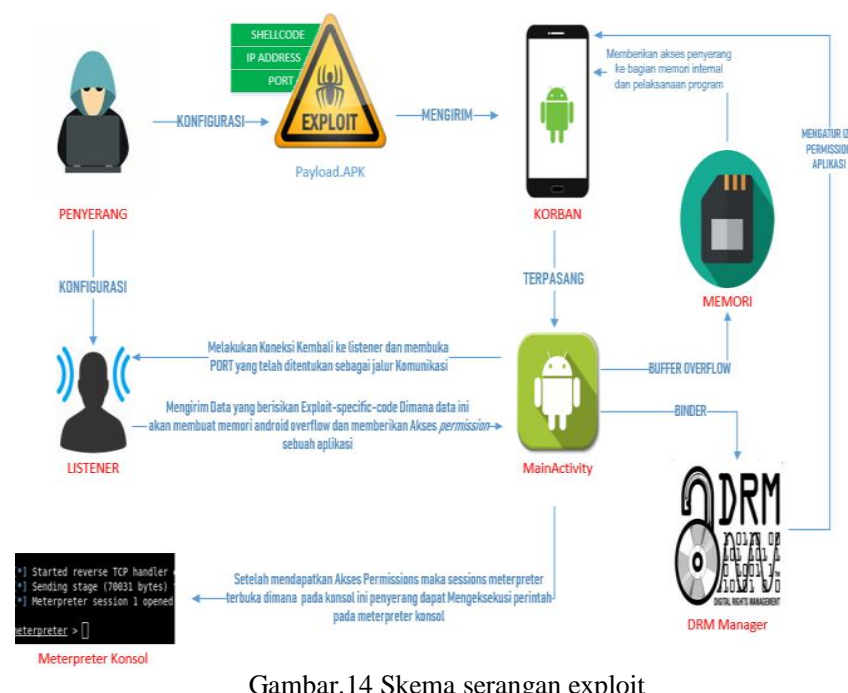

Berikut adalah skema serangan exploit dengan gambaran pada arsitektur android :

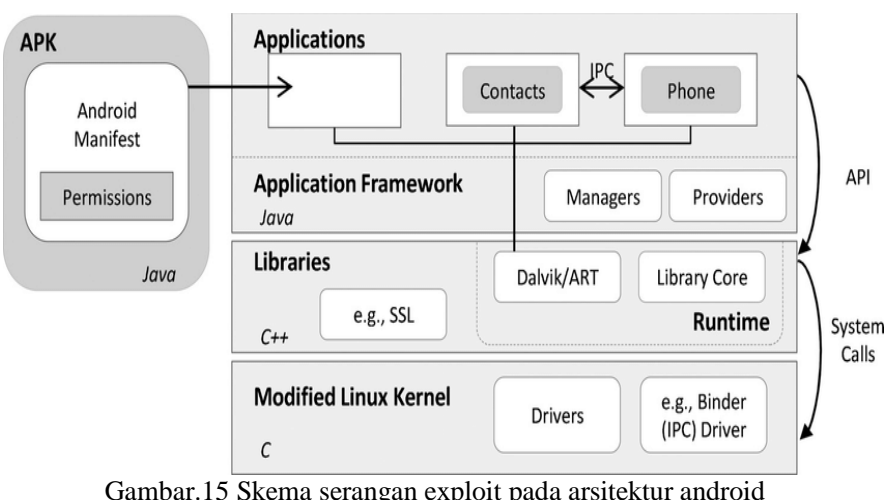

Pada saat payload terpasang pada perangkat android dengan nama mainactivity berada pada layer application, aplikasi MainActivity mendapat verifikasi dari servis Dalvik/ART dengan memanfaatkan bug memori overflow. Setelah terverifikasi aplikasi MainActivity dapat memodifikasi servis binder (IPS) pada android, dimana MainActivity mendapatkan akses permissions sebuah aplikasi.

\section{REFERENSI}

[1] K. Shivam, S. Rupal, Android backdoors, vol. 4 no. 2, hal 1-2, Feb.2017.

[2] R. Chandel. (2016). Penetration testing in smb protocol using metasploit. [Online]. Available http://www.hackingarticles.in/penetration-testing-in-smb-protocolusing-metasploit.

[3] T. N. Manjunatha,M. S. Shashindhar,G. Vinay, S. Vittal, "Survery on metasploit framework," vol. 4, no. VIII, hal 1, Agustus.2016.

[4] R. Choudhary, M. Khurana, "Exploitation of PDF Reader Vulnerabilites using metasploit tool,” hal 2-4. Sept.2017.

[5] U. Timalsina, K. Gurung, "Metasploit framework with kali linux," April 2015.

[6] A. Gonsalves, C. Kulkarni, Ketankokane, P. Mali, M. Mehra, “a tool for preventing the metasploit attack on the android OS," vol. 5. ISSN 2249-5789, hal 326.

[7] H. Shewale, S. Patil, V. Deshmukh, P. Singh, "Analysis of android vulnerabilities and modern exploitation techniques," vol. 05 no. 1 , Maret 2014

[8] Dana, (2016), October 10. Backdoor Apk. [Online]. Available : https://github.com/dana-at-cp/backdoor-apk/.

[9] K. A. Zaabi, "android device hacking tricks and countermeasures".

[10] Z. T. Brunner, "Buffer Overflow in multple android DRM service," , [Online], Available : https://blog.zimperium.com/cve-201713253-buffer-overflow-multiple-android-drm-services/.

[11] buffer overflow, [Online], Avaiable https://www.enisa.europa.eu/topics/csirts-ineurope/glossary/buffer-overflow.

[12] android.drm, [Online] , Available https://developer.android.com/reference/android/drm/packagesummary.

[13] R. Shenoy, “Metasploit For beginners, ” Jan, 2017.

[14] A. Feizollah, B. N. Anuar, R. Salleh,'The evolotuion of android malware and android analysis techniques," Vol. 49, No. 4, Jan 2017.

[15] script ezsploit, [Online], Available : Juli) https://github.com/rand0m1ze/ezsploit.

[16] I. Mardianto,Kuswandi, "Implementasi keamanan pada transaksi data menggunakan sertifikat Digital X.509.” Vol. VIII, No.1, Juni 2016. 